\title{
1 Molecular Basis of Antibiotic Self-Resistance in a Bee Larvae
}

\section{Pathogen}

3 Tam Dang ${ }^{1}$, Bernhard Loll ${ }^{2}$, Sebastian Müller ${ }^{1}$, Ranko Skobalj ${ }^{1}$, Julia Ebeling ${ }^{3}$, Timur

4 Bulatov $^{1}$, Sebastian Gensel ${ }^{1}$, Josefine Göbel ${ }^{3}$, Markus C. Wahl ${ }^{2,4}$, Elke Genersch ${ }^{3,5}$, Andi

5 Mainz $^{1}$, Roderich D. Süssmuth ${ }^{1, \#}$

6

$7 \quad{ }^{1}$ Institut für Chemie, Technische Universität Berlin, Berlin, Germany

$8{ }^{2}$ Institut für Chemie und Biochemie, Strukturbiochemie, Freie Universität Berlin, Berlin,

9 Germany

$10{ }^{3}$ Department of Molecular Microbiology and Bee Diseases, Institute for Bee Research,

11 Hohen Neuendorf, Germany

$12{ }^{4}$ Macromolecular Crystallography, Helmholtz Zentrum Berlin für Materialien und Energie,

13 Berlin, Germany

$14{ }^{5}$ Institut für Mikrobiologie und Tiersuchen, Fachbereich Vetrinärmedizin, Freie Universität

15 Berlin, Berlin, Germany

$16{ }^{*}$ Correspondence to: roderich.suessmuth@tu-berlin.de

\section{Abstract}

18 Paenibacillus larvae, the causative agent of the devastating honey-bee disease American 19 Foulbrood, produces the cationic polyketide-peptide hybrid paenilamicin that displays high 20 antibacterial and antifungal activity. Its biosynthetic gene cluster contains a gene coding for the $\mathrm{N}$-acetyltransferase PamZ. We show that PamZ acts as self-resistance factor in $\mathrm{P}$. larvae by deactivation of paenilamicin. Using tandem MS, NMR spectroscopy and synthetic diastereomers, we identified the $\mathrm{N}$-terminal amino group of the agmatinamic acid as the $\mathrm{N}$ acetylation site. These findings highlight the pharmacophore region of paenilamicin, which we very recently identified as a new ribosome inhibitor. Here, we further elucidated the crystal structure of PamZ:acetyl-CoA complex at $1.34 \AA$ resolution. An unusual tandem-domain architecture provides a well-defined substrate-binding groove decorated with negativelycharged residues to specifically attract the cationic paenilamicin. Our results will help to understand the mode of action of paenilamicin and its role in pathogenicity of $P$. larvae to fight American Foulbrood.

\section{Introduction}

32 Pollination of wild and cultivated flowering plants is an indispensable ecosystem service, which 33 is mainly provided by pollinating insects. Among the insect pollinators, managed honey bee colonies play a particularly important role in agriculture, where they are widely used as commercial pollinators and contribute to $35 \%$ of the production volume of global food crops ${ }^{1}$. 
In order to secure human food supply, it is therefore important to ensure the health of honey bees, which is continuously threatened by various viral, bacterial and fungal pathogens as well as metazoan parasites ${ }^{2}$.

The Gram-positive, facultative anaerobic, spore-forming bacterium, Paenibacillus larvae ( $P$. larvae), is the causative agent of the epizootic American Foulbrood (AFB) of honey bees ${ }^{3}$. AFB is a fatal intestinal infection of the honey bee brood initiated in first instar larvae by ingestion of spore-contaminated food. The distribution of the spores, the infectious form of $P$. larvae, within a colony and between colonies, also within apiary and between apiaries ${ }^{4}$, consequently leads to honey bee colony losses. P. larvae comprises the four well-described genotypes ERIC I to ERIC IV ${ }^{3}$ which differ in virulence on the larval ${ }^{5}$ and colony level ${ }^{6}$ as well as in pathogenesis strategies employed to kill the host ${ }^{7}$. The existence of another ERIC genotype, ERIC V, has recently been proposed ${ }^{8}$. From contemporary outbreaks of AFB all

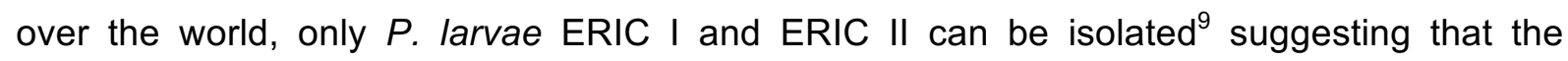
hypervirulent genotypes ERIC III to ERIC V did not become established in the honey bee population.

In our quest to find sustainable control measures against this most serious bacterial disease of honey bees, we started to unravel AFB pathogenesis by analyzing the interaction between $P$. larvae and honey bee larvae on a molecular level. We identified several virulence factors of $P$. larvae ERIC I and ERIC II and showed that two AB toxins ${ }^{10,11}$, a chitin-degrading enzyme ${ }^{12,13}$ and also an S-layer protein ${ }^{14,15}$ have a pivotal role in the virulence of this pathogen and that $P$. larvae also produces various secondary metabolites ${ }^{16}$. Bacterial secondary metabolites, with polyketides and (non-)ribosomal peptides as important representatives, provide highly valuable lead structures, among them antibiotics with novel modes of actions for drug development to fight various infectious diseases ${ }^{17,18}$. Secondary metabolites can also act as virulence(-like) factors, functioning as signal molecules in gene regulation of defense or growth mechanisms ${ }^{19-21}$. The search for secondary metabolites produced by $P$. larvae led to the structural elucidation of paenilamicin that shows cytotoxic, antibacterial and antifungal activities $^{22,23}$. It is currently assumed that paenilamicin is produced as a defense molecule against microbial competitors, since only $P$. larvae can be isolated as a pure culture from AFBdiseased larval cadavars, while other microbial competitors are absent in the degradation process of the infected larvae ${ }^{24}$.

Paenilamicin is a linear, cationic aminopolyol peptide antibiotic and is synthesized via an unusual nonribosomal peptide synthetase-polyketide synthase (NRPS-PKS) hybrid assembly line that exhibits several fascinating biosynthetic features. It contains unusual structural motifs such as galantinamic acid (Glm), agmatinamic acid (Aga), $N$-methyldiaminopropionic acid (mDap), galantinic acid (Gla) and a 4,3-spermidine (Spd) at the C-terminus (Figure 1). $P$. larvae produces a mixture of paenilamicin variants A1, A2, B1 and B2. They only differ in 
two positions of the paenilamicin backbone: at the $\mathrm{N}$-terminus and in the center between mDap1 and Gla. Either a lysine (series A) or an arginine (series B) is activated by the adenylation domain of NRPS1 (Figure 1). The amino acid residue between mDap1 and Gla is a lysine (series 1) or an ornithine (series 2) assigned to be incorporated by NRPS4 (pamD), respectively (Figure 1).

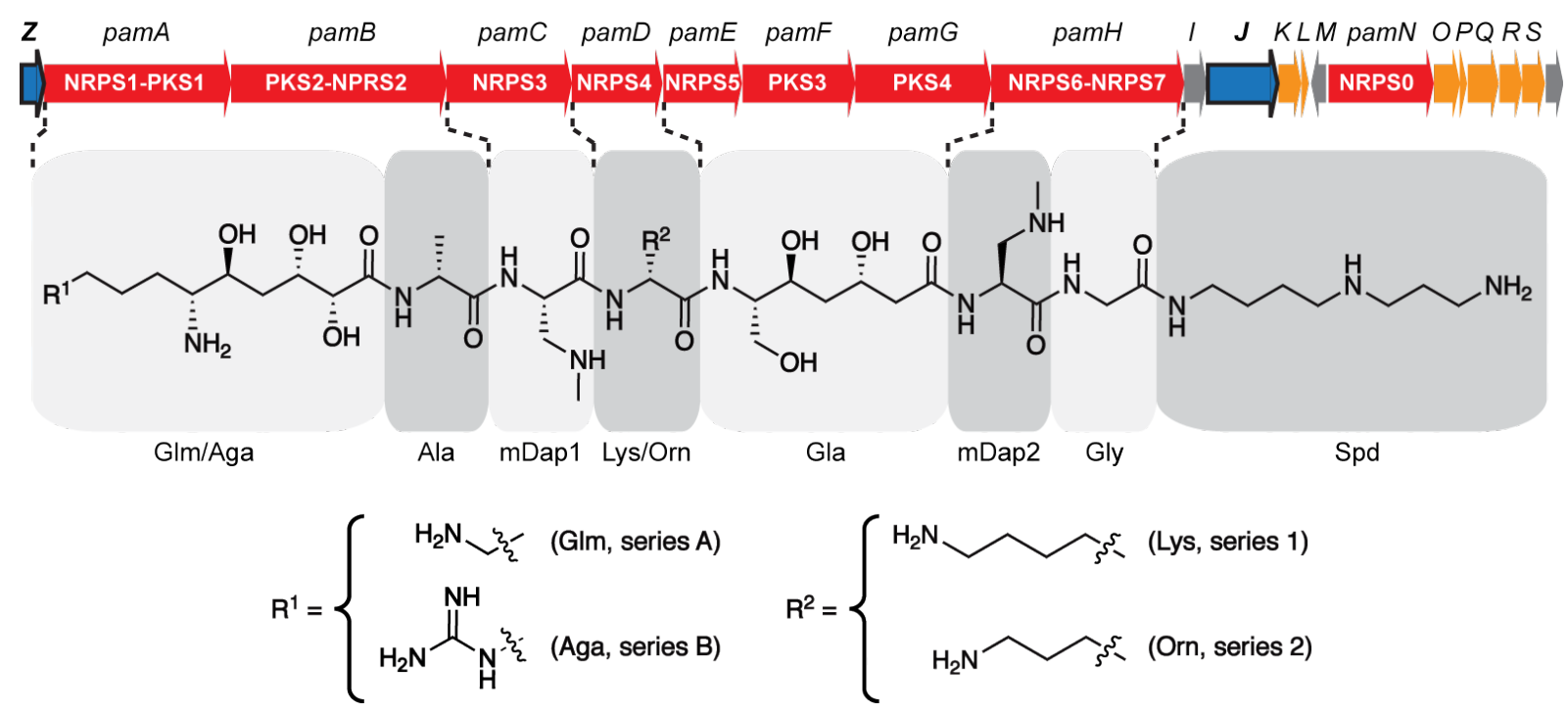

Figure 1. Biosynthetic gene cluster and structure of paenilamicin variants. The pam gene cluster ${ }^{22}$ contains core biosynthetic (red), auxiliary biosynthetic (orange), resistance (pamZ and pamJ; blue) and other (grey) genes and expresses the NRPS-PKS hybrid biosynthetic machinery for the production of paenilamicin A1 (GIm, Lys), A2 (GIm, Orn), B1 (Aga, Lys) and B2 (Aga, Orn). Abbreviations are listed as follows: galantinamic acid (GIm), agmatinamic acid (Aga), lysine (Lys), ornithine (Orn), alanine (Ala), $\mathrm{N}$-methyldiaminopropionic acid (mDap), galantinic acid (Gla), glycine (Gly), 4,3-spermidine (Spd).

The pam gene cluster harbors a gene encoding the putative acetyl-CoA-dependent $N$ acetyltransferase, PamZ, which belongs to the Gcn5-related $\mathrm{N}$-acetyltransferase (GNAT) superfamily ${ }^{25,26}$. One prominent member of this superfamily is the bacterial aminoglycoside $\mathrm{N}$ acetyltransferase (AAC) that plays an important role in antibiotic resistances, particularly in clinical and environmental settings ${ }^{27}$. Aminoglycoside antibiotics have been widely used in the treatment of bacterial infections but they rapidly lose activity against multi-resistant bacteria due to adaptation and the development of resistance. By contrast, self-resistance is an innate, non-adaptation-based mechanism for the protection against self-produced antimicrobial agents. Since self-produced antimicrobial agents could also harm the bacterial host, selfresistance is critical for survival and territorial competition.

Our results demonstrate the deactivation of paenilamicins by the regio- and stereoselective self-resistance protein PamZ including its high-resolution crystal structure that shows how its tandem-domain arrangement organizes substrate binding. Together with a parallel study ${ }^{28}$, in which we report on the total synthesis and the biological evaluation of paenilamicin, we have 
here unambiguously identified the $\mathrm{N}$-terminal building block of paenilamicins as an essential switch for target binding, biological activity and self-resistance.

\section{Results}

\section{Regio- and stereoselective $\mathbf{N}$-acetylation of paenilamicin by PamZ}

To confirm our hypothesis that PamZ (NCBI accession no.: WP_023484187) is an acetyl-CoAdependent $\mathrm{N}$-acetyltransferase that targets paenilamicins, we monitored PamZ-mediated antibacterial effects in vitro by agar diffusion assays against Bacillus megaterium (B. megaterium) as indicator strain as well as by mass spectrometry (MS) and nuclear magnetic resonance (NMR) spectroscopy. To this end, the pamZ gene was amplified from the wild type (WT) P. larvae ERIC II strain, inserted into the commercial pET28a(+) vector and transformed into E. coli BL21-Gold(DE3) for heterologous expression. PamZ was then purified (Figure S1) and used for the assays including four native paenilamicin variants as substrates and acetyl-CoA as co-substrate. The paenilamicin variants were purified from $P$. larvae ERIC I and ERIC II, which preferably produce the paenilamicin mixtures $A 2 / B 2$ and A1/B1, respectively (Figure 1, Figure S2). In addition, we also tested synthetic paenilamicin B2 $(\text { PamB2_3 })^{28}$.

The agar diffusion assays clearly showed that paenilamicins incubated with PamZ and acetyl-CoA were not able to inhibit the growth of $B$. megaterium, whereas antibacterial activity was observed in the absence of acetyl-CoA and/or PamZ (Figure 2). This loss of biological activity correlated with the conversion of paenilamicins to the corresponding $\mathrm{N}$ acetylpaenilamicins as observed by HPLC-ESI MS. ESI mass spectra revealed that the massto-charge ratios of natural and synthetic paenilamicins exhibited a characteristic mass shift of $42 \mathrm{Da}$ indicative of the addition of an acetyl group (Figure S3-S7).

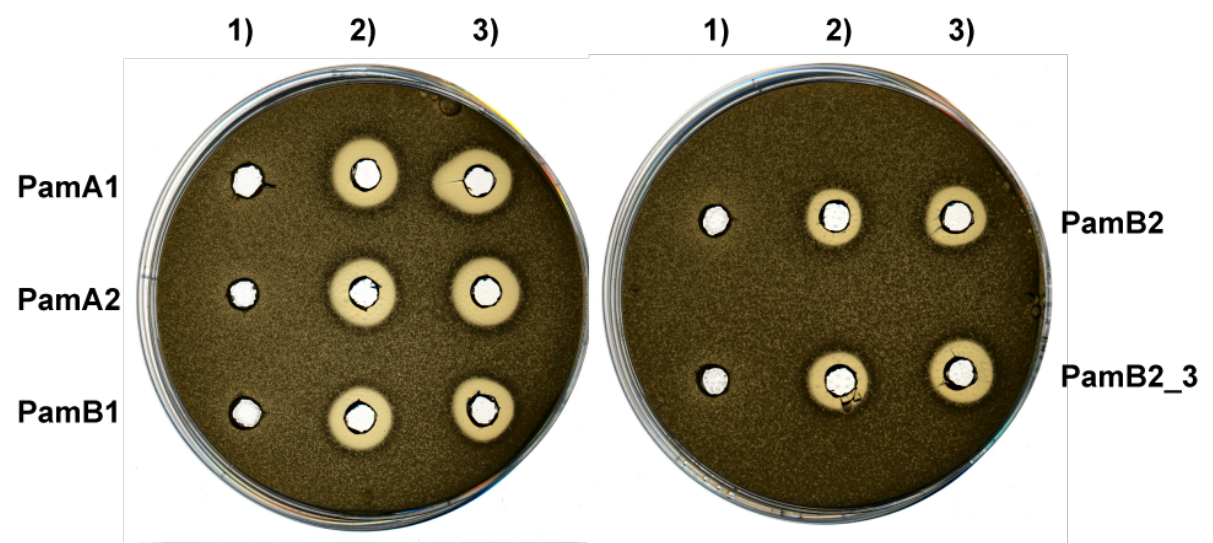

Figure 2. Deactivation of paenilamicins through PamZ-mediated $\mathbf{N}$-acetylation tested by agar diffusion assay against $B$. megaterium as indicator strain. Paenilamicin variants (PamA1, A2, B1, B2) isolated from $P$. larvae and synthetic paenilamicin B2 (PamB2_3) were incubated in vitro with both acetyl-CoA and PamZ (1), acetyl-CoA only (2) or PamZ only (3). Samples 2 and 3 are negative controls and indicate the lack of bacterial growth. 
Paenilamicin contains several primary and secondary amino groups that are potential candidates for $\mathrm{N}$-acetylation. To determine the site of acetylation, we monitored PamZmediated effects in fingerprint tandem MS and NMR spectra of paenilamicin before and after treatment with PamZ/acetyl-CoA. Besides the mass shift of $42 \mathrm{Da}$ for the acetylation, characteristic $\mathrm{MS}^{2}$ fragmentation patterns originated from the difference between $\mathrm{GIm}$ and Aga residues in series $A$ and $B(+28 \mathrm{Da})$ as well as the difference between Lys and Orn residues in series 1 and $2(+14 \mathrm{Da}) . \mathrm{MS}^{2}$ fragmentation mainly resulted in fragment ions $\mathrm{b}_{4}, \mathrm{y}_{4}$ and $\mathrm{y}_{6}$ of each paenilamicin and $\mathrm{N}$-acetylpaenilamicin variant acquired by collision-induced dissociation (Table S1). Fragment ion $b_{4}$ varied depending on the paenilamicin series showing mass shifts of $14 \mathrm{Da}$ and $28 \mathrm{Da}$. Importantly, we observed a mass shift of $42 \mathrm{Da}$ only for fragment ion $\mathrm{b}_{4}$, indicating acetylation in the $\mathrm{N}$-terminal half of paenilamicin. By contrast, the fragment ions $\mathrm{y}_{4}$ and $y_{6}$ did not exhibit any mass shifts of 42 Da between paenilamicins and $\mathrm{N}$ acetylpaenilamicins. Thus, we excluded acetylation in the C-terminal half of paenilamicin

141 (Figure S8-S18). In addition, we detected and isolated small amounts of $N$-acetylpaenilamicin

$142 \mathrm{~A} 1, \mathrm{~B} 1$ and B2 from supernatants of $P$. larvae ERIC I and ERIC II (Figure S19), and compared 143 them with our products formed in vitro. The $\mathrm{MS}^{2}$ fragmentation analysis confirmed that the 144 mono-acetylation in the N-terminal half of paenilamicin also occurred in vivo (Figure S20-S22).

145 The $\mathrm{MS}^{2}$ experiments did not reveal whether the N-terminal amino group of Aga- 6 or its side 146 chain (amino/guanidino group) was acetylated.

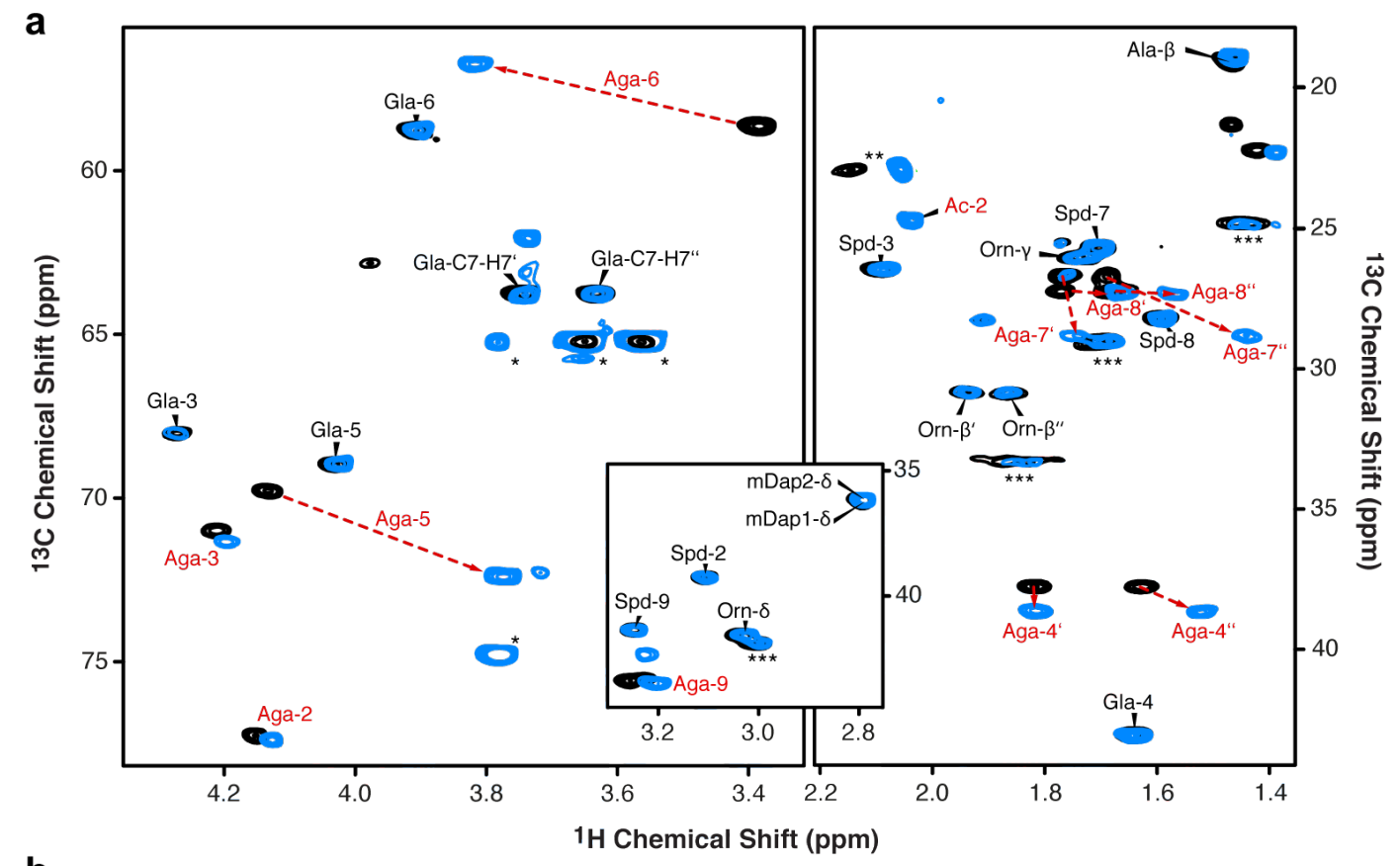

b<smiles>CNC[C@H](NC(=O)C[C@H](O)C[C@H](O)[C@H](CO)NC(=O)[C@H](CCCN)NC(=O)[C@H](CNC)NC(=O)[C@H](C)NC(=O)[C@H](O)[C@H](O)C[C@H](O)[C@H](CCCNC(=N)N)NC(C)=O)C(=O)NCC(=O)NCCCCNCCCN</smiles> 
Figure 3. Identification of the $\mathbf{N}$-acetylation site through 2D NMR spectroscopy. a Overlay of relevant ${ }^{1} \mathrm{H}-{ }^{13} \mathrm{C}$ HSQC sections of paenilamicin B2 (black) and $\mathrm{N}$-acetylpaenilamicin B2 (blue). Stronglyperturbed cross-peaks are highlighted with red labels. Known impurities are labeled with one, two and three asterisks arising from glycerol, acetic acid and residual purification traces of paenilamicin B1, respectively. b Significant chemical shift perturbations (CSPs) are indicated as circles (see legend for color code) in the chemical structure of $\mathrm{N}$-acetylpaenilamicin B2.

To ultimately identify the functional group that is modified by $\mathrm{PamZ}$, we acquired ${ }^{1} \mathrm{H}-{ }^{13} \mathrm{C}$ hetero-nuclear single-quantum coherence (HSQC) NMR spectra of paenilamicin B2 before and after incubation with PamZ/acetyl-CoA. Although both spectra were mostly superimposable, severe chemical shift perturbations (CSPs) were observed for a minor

158 fraction of cross-peaks (Figure 3a). Mapping CSPs onto the structure of paenilamicin B2 revealed a well-defined region comprising the $\mathrm{N}$-terminal half, with the strongest effect being located at Aga-6 (Figure 3b, Table S2). N-acetylpaenilamicin B2 also showed an additional cross-peak compared to paenilamicin B2, which we tentatively assigned to the methyl moiety of the newly attached acetyl group (Figure 3a). Our data unequivocally demonstrated that PamZ mono- $\mathrm{N}$-acetylates the $\mathrm{N}$-terminal amino group at Aga-6 position of paenilamicin and thereby abolishes its antibacterial activity. Ultimately, this result is further supported by two synthetic diastereomers of paenilamicin B2 with L- instead of the native D-configuration at Aga6 (PamB2_1 and PamB2_2), that were both antibacterially less active ${ }^{28}$ and that were not modified by PamZ (Figure 4, Figure S23).

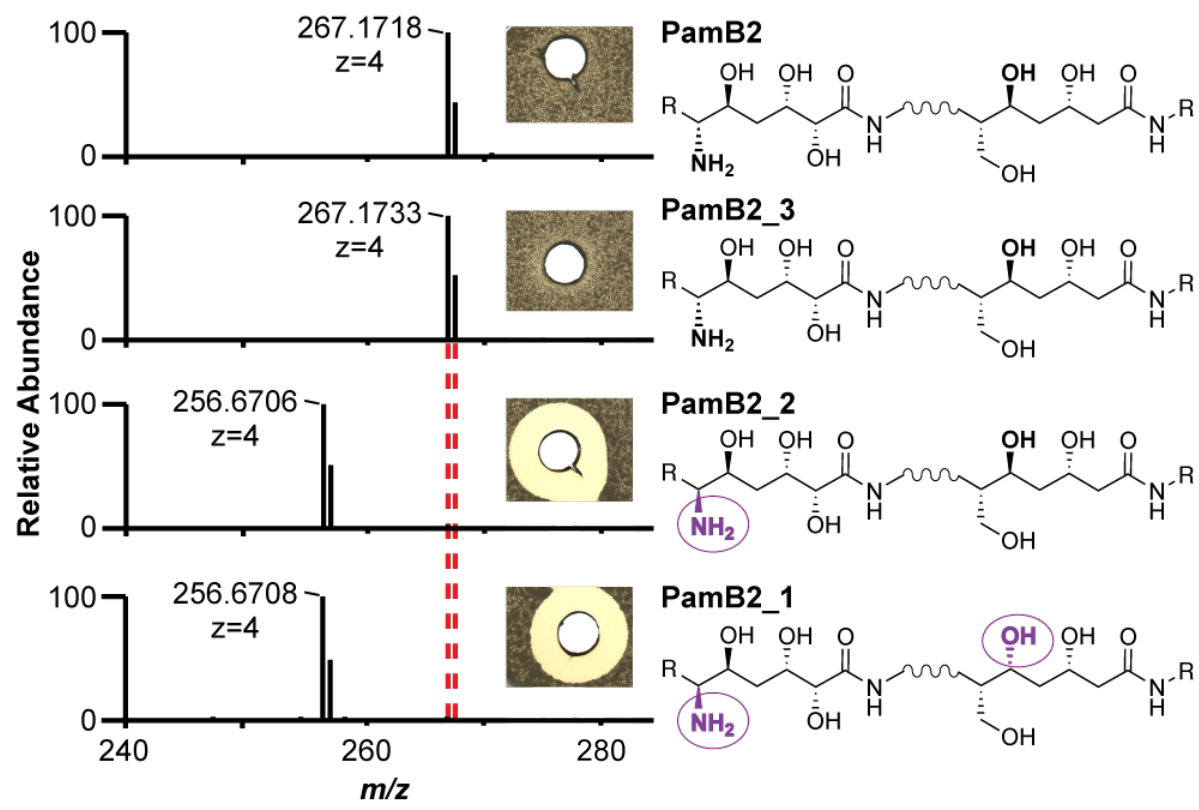
synthetic paenilamicin B2 (PamB2_3) and synthetic diastereomers of paenilamicin B2 (PamB2_2,

171 PamB2_1) were incubated with PamZ and acetyl-CoA in vitro and tested in an agar diffusion assay 172 against Bacillus megaterium (insets). Each single reaction was verified by HPLC-ESI MS. Dashed lines 
indicate the mass shift of $42 \mathrm{Da}(4 \times 10.5 \mathrm{Da})$ due to $\mathrm{N}$-acetylation. Changes in stereoconfiguration are highlighted in purple and circles.

\section{The structure of PamZ:acetyl-CoA binary complex}

176 A BLAST ${ }^{29}$ search indicated that PamZ belongs to the GNAT superfamily with a sequence identity of $31 \%$ to the $N$-acetyltransferase, $Z m a R$, whose structure has not yet been determined and which confers resistance against the aminopolyol peptide antibiotic, zwittermicin A, in Bacillus cereus UW85 (Figure S24) ${ }^{30}$. We elucidated the crystal structure of PamZ in complex with acetyl-CoA at a resolution of $1.34 \AA$ by using the uncharacterized $N$ acetyltransferase from Streptococcus suis 89/1591 (PDB-ID: 3g3s) for molecular replacement (Table S3). The electron density was of excellent quality, allowed the modeling of the entire comprises an N-terminal domain (NTD, residues 1-128, secondary structure elements indicated by primes) and a C-terminal domain (CTD, residues 140-275) which both adopt the characteristic GNAT fold (Figure 5a) ${ }^{31}$. The two tandem-GNAT domains, that may have originated from a gene duplication event, share low sequence identity $(<20 \%)$ and are connected by an $\alpha$-helical linker ( $\alpha_{\text {bridge }}$, residues 129-139). The overall fold of each domain is very similar to that of bacterial aminoglycoside $N$-acetyltransferases (AACs), as pairwise structural alignments with several AACs (PDB-IDs: $1 \mathrm{bo} 4,1 \mathrm{~m} 4 \mathrm{i}, 1 \mathrm{~s} 3 \mathrm{z}$ ) gave root-mean square deviations (RMSDs) of 2.9-4.2 $\AA$ for both the NTD and CTD (Figure S26) ${ }^{32}$. A structural superimposition between the NTD and CTD of PamZ yielded an RMSD of $4.2 \AA$ for 75 pairs of $\mathrm{C}_{\alpha}$ atoms (Figure S27) ${ }^{32}$.

However, a comparison with the typical GNAT fold revealed several unique features in PamZ. Instead of two N-terminal $\alpha$-helices, $\alpha 1$ and $\alpha 2$, both domains of PamZ contain three short helical segments, $\alpha 0-\alpha 1-\alpha 2$, which pack onto one face of the central antiparallel $\beta$-sheet, $\beta 2-\beta 3-\beta 4$, whereas helix $\alpha 3$ buries its other side. A kink in the backbone conformation of strand $\beta 3$, involving residues T199 and C200, causes a strong right twist and thus a distortion of the antiparallel $\beta 3-\beta 4$ arrangement, which led us to discriminate these strands as $\beta 3 a / \beta 3 b$ and $\beta 4 a / \beta 4 b$ (Figure 5a). The central $\beta$-sheet is extended by strand $\beta 5^{\prime}$ in the NTD, whereas the CTD shows the characteristic $\beta$-bulge of GNAT enzymes - a V-shaped cavity between strands $\beta 4 \mathrm{~b}$ and $\beta 5$ accommodates the pantetheine segment of CoA (Figure 6a). Furthermore, the well-conserved pyrophosphate-binding loop (P-loop) of the GNAT family (R/Q-X-X-G-X-A/G) ${ }^{25}$ is only present in the CTD of PamZ (Q-N-K-G-L-A) between strand $\beta 4 b$ and helix $\alpha 3$

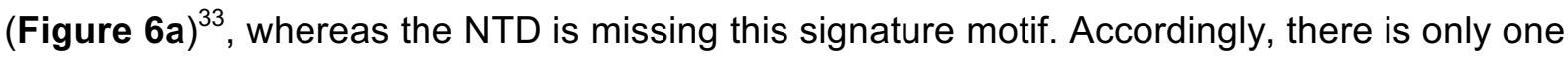
acetyl-CoA molecule canonically bound in the PamZ structure, namely to the CTD. 
a

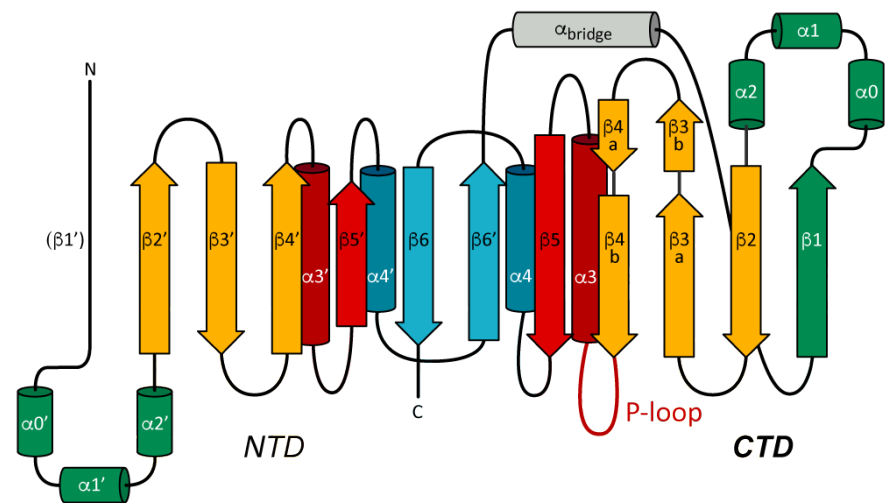

b
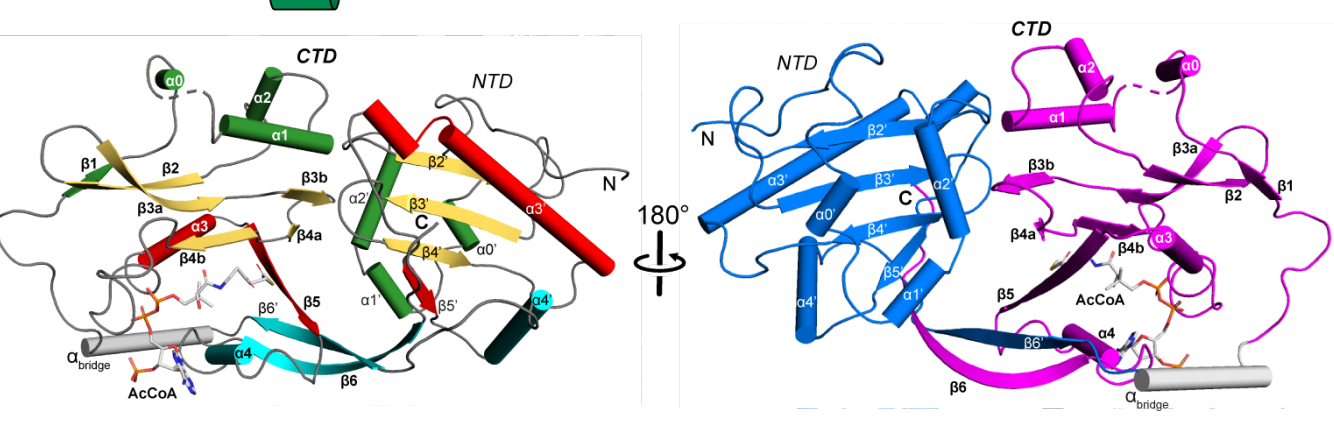

.
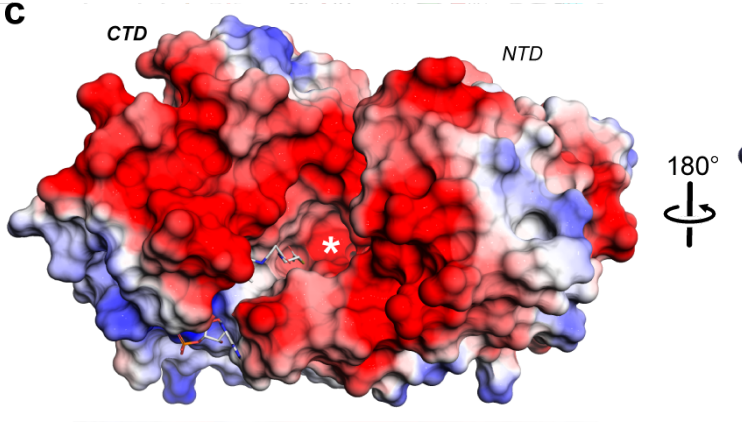

$+6 \mathrm{kT} / \mathrm{e}-$

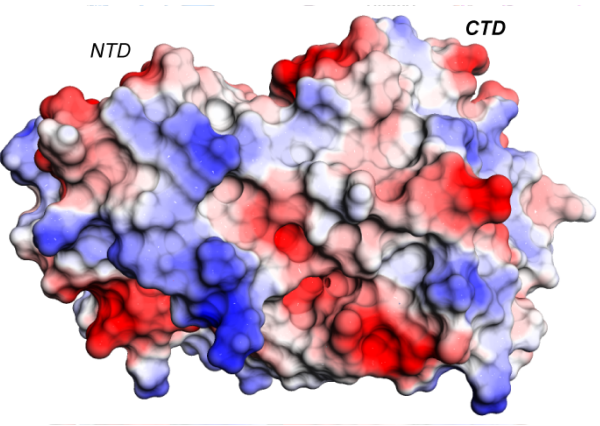

Figure 5. X-ray crystal structure of Gcn5-related $\mathbf{N}$-acetyltransferase PamZ. a Structural topology of PamZ with its characteristic tandem-GNAT fold. The protein structure is divided into an N-terminal (NTD) and a C-terminal (CTD) domain. Color coding of protein regions follows that of other bacterial GNATs, such as aminoglycoside $N$-acetyltransferases (AACs) ${ }^{31}$. b Cartoon representations of PamZ

212 from two perspectives. The first perspective (left) follows the color code as in a). Acetyl-CoA (AcCoA)

213 bound to the P-loop and $\beta$-bulge of the CTD is depicted as sticks. The $\beta$-bulge is formed by strands $\beta 4 \mathrm{~b}$ 214 and $\beta 5$. The tandem-GNAT domains are highlighted (right) in blue (NTD) and purple (CTD). Secondary structure elements are labeled according to the protein topology. $\mathbf{c}$ Identical view as in panel b) with the electrostatic potential mapped on the surface of PamZ, illustrating positive (blue) and negative (red) charges. The acetyl group attached to CoA (sticks) points into the active site highlighted by an asterisk.

Hence, we concluded that the NTD is incompetent of binding acetyl-CoA and rather plays a structural role, in particular for substrate binding (see below). Notably, many GNAT enzymes exist as homodimers in solution with various arrangements of the monomer-monomer interface ${ }^{31}$. Likewise, AACs have often been crystallographically observed in a homodimeric

222 state, although their quaternary structure in solution may vary ${ }^{34}$. PamZ exists as a monomer, 223 both in solution and in the crystal (Figure S28). However, the tandem-GNAT domain 
constellation of PamZ achieves an intramolecular domain-domain interface that resembles that of some GNAT homodimers. There are several GNAT enzymes that utilize domain swapping of strand $\beta 6$ to stabilize their homodimeric structure ${ }^{33,35,36}$. Interestingly, a major interface in PamZ is achieved by domain-swapping of strand $\beta 6\left(\beta 6^{\prime}\right)$, which inserts between strands $\beta 5^{\prime}$ and $\beta 6^{\prime}$ ( $\beta 5$ and $\beta 6$ ) of the opposing domain and thus forms an extended, antiparallel and strongly-twisted $\beta$-sheet throughout the enzyme (Figure $\mathbf{5 b}$ ). This $\beta$-sheet is only interrupted by the $\beta$-bulge in the CTD accommodating the cofactor and allowing the amide groups of its pantetheine portion to form pseudo- $\beta$-sheet hydrogen-bonds to strand $\beta 4$ b (Figure 6a). A very similar tandem arrangement of a pseudo-GNAT NTD and a canonical GNAT CTD can be found in the template protein (PDB-ID: 3g3s). Another example is the structure of mycothiol synthase MshD from Mycobacterium tuberculosis, which is also organized as a tandem repeat of two GNAT domains with a catalytically inactive NTD ${ }^{37}$.

PamZ appears to utilize its NTD to form a well-defined substrate pocket with strands $\beta 5$ and $\beta 6$ ' representing its floor. A second interface between the NTD and CTD is accomplished through tight packing of helix $\alpha 2$ ' onto the small $\beta 3 b-\beta 4 a$ sheet. Further interactions involve helix $\alpha 2$ of the CTD and the loops between $\alpha 2^{\prime}$ and $\beta 2$ ' as well as $\beta 3^{\prime}$ and $\beta 4$ ' of the NTD. These inter-domain contacts fully cover the central groove that is normally found at the interface of homodimeric structures of GNAT enzymes and restrict substrate entry to the opening that is also used by the cofactor. This remaining cleft between the two domains of PamZ is decorated with several acidic residues (e.g. E89, E116, E118, D120, D162, D170, D215, E216, E217, E218, E272, E274 and the C-terminus) and thus deploys a large negatively-charged surface to attract its polycationic substrate (Figure 5c). A corridor that lies aside and beyond the acetyl group of the cofactor is approximately 7-8 $\AA$ deep and 8-9 $\AA$ wide with respect to the thioester carbonyl atom. Although we did not obtain crystals of a ternary PamZ-acetyl-CoA-paenilamicin complex, the position of acetyl-CoA, the well-defined shape of the neighboring pocket and our knowledge about the substrate's N-terminal acetylation site allows us to predict that the GIm/Aga side-chain of paenilamicin very likely penetrates into this pocket. Acidic residues D25 (loop between $\alpha 1^{\prime}$ and $\alpha 2$ '), E122 ( $\beta 6$ '), and E208 ( $\left.\beta 4 a\right)$ are wellpositioned within the pocket to accommodate and stabilize the guanidine group of Aga, as well as to tolerate the $\mathrm{N} \zeta$ amine of $\mathrm{Glm}$. Other residues that shape the substrate pocket include T58/T59 (loop between $\beta 3^{\prime}$ and $\beta 4^{\prime}$ ), T98 ( $\left.\beta 5^{\prime}\right)$ and Y124 ( $\beta 6^{\prime}$ ) of the NTD as well as C200/Y201 $(\beta 3 b)$ and S245/F247 ( $\beta 5)$ of the CTD (Figure 6c). This shows that both domains most likely contribute to substrate recognition. Moreover, the structure of PamZ explains its regioselectivity: if PamZ was to modify e.g. the terminal amino group of spermidine in paenilamicin, the enzyme would not require such a deep substrate-binding pocket. The architecture of the central groove between the NTD and CTD has evolved to optimally 

pocket, as they would experience significantly less binding stabilization.

a

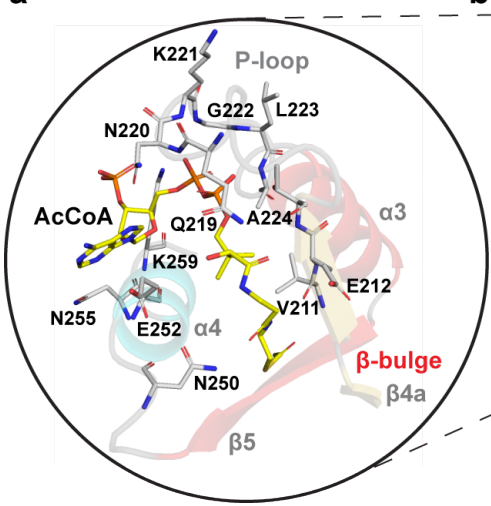

b

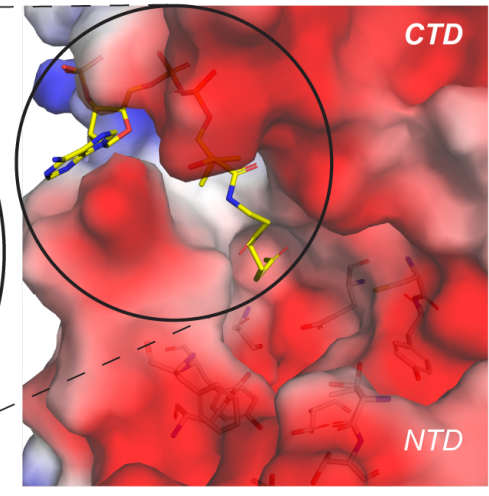

C

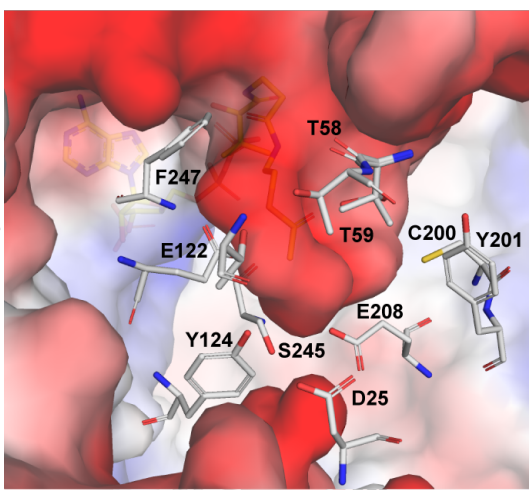

Figure 6. Active site of PamZ. a Motifs $A(\beta 4-\alpha 3)$ and $B(\beta 5-\alpha 4)$ located in the C-terminal domain (CTD) interact with co-substrate acetyl-CoA. b Close-up view of the active site displaying the negatively charged groove (color code as in Figure 5c). c Highlighted amino acid residues with hydrogen-donating and -accepting groups form the groove and interact with the substrate paenilamicin.

Such accommodation of GIm/Aga in the substrate pocket would position the N-terminal amino group of Aga-6 close to the thioester carbonyl of the cofactor. An active-site aspartate or glutamate residue commonly acts as a general base to trigger the $N$-acetylation reaction by deprotonation of the amine followed by a nucleophilic attack at the carbonyl of the thioester ${ }^{34}$. In PamZ, the side-chains of E122 ( $\left.\beta 6^{\prime}\right)$ as well as E208 ( $\left.\beta 4 a\right)$ exhibit an interatomic distance of approximately $7 \AA$ to the carbonyl atom of acetyl-CoA and thus might be in close proximity to the N-terminal amino group of Aga-6 (Figure 6c). Residue S245 ( $\beta 5)$ is sandwiched between E122 and E208, and may mediate deprotonation and/or proton shuttling. Furthermore, we cannot exclude the involvement of water molecules during proton transfer. An oxyanion hole as described for myristoyl-CoA transferase ${ }^{38}$ is not present in PamZ, but the amide proton of V211 ( $\beta 4 b$ ) facilitates hydrogen-bonding to the carbonyl oxygen of the thioester, which would increase the electrophilicity of the carbonyl carbon and stabilize the tetrahedral transition state after nucleophilic attack.

\section{Self-resistance mechanism of $\boldsymbol{P}$. larvae}

The deactivation of paenilamicin through formation of $N$-acetylpaenilamicin by the action of PamZ (Figure S3-S7) implicates that the enzyme may confer self-resistance to the producer strain $P$. larvae. To test this hypothesis, we exposed the deletion mutant $P$. larvae $\triangle p a m Z$ to a mixture of paenilamicin A1/B1 in an agar diffusion assay. The mixture, which was purified from $P$. larvae ERIC II, inhibited bacterial growth of the deletion mutant $\Delta p a m Z$, but not that of the WT strain (Figure 7a). 
This result demonstrated that $P$. larvae requires the resistance gene, pam $Z$, to protect itself from the deleterious effects of its own antibacterial agent, paenilamicin. For further experimental support, we analyzed supernatants and cell pellets of $P$. larvae WT and $\Delta p a m Z$ for paenilamicins and $\mathrm{N}$-acetylpaenilamicins. In cell lysates of $P$. larvae WT, we exclusively found $\mathrm{N}$-acetylpaenilamicin, whereas for the deletion mutant $\Delta$ pamZ only unmodified paenilamicin (Figure 7b) was detected. From paenilamicin isolates of the WT strain, primarily paenilamicin and only small amounts of $\mathrm{N}$-acetylpaenilamicin were found in the supernatant by HPLC-ESI MS (Figure S2). These findings demonstrate that the self-resistance factor PamZ enables $P$. larvae WT to acetylate and thus inactivate intracellular paenilamicin.

a

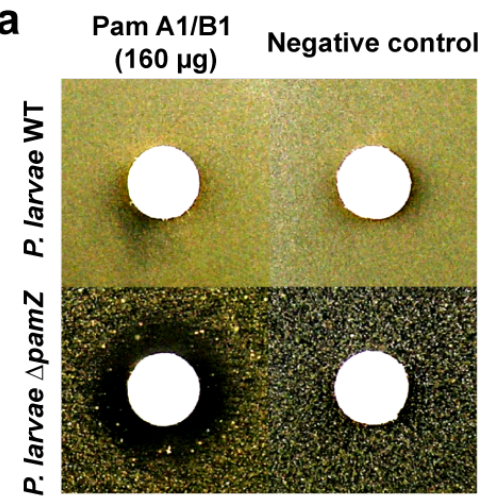

b

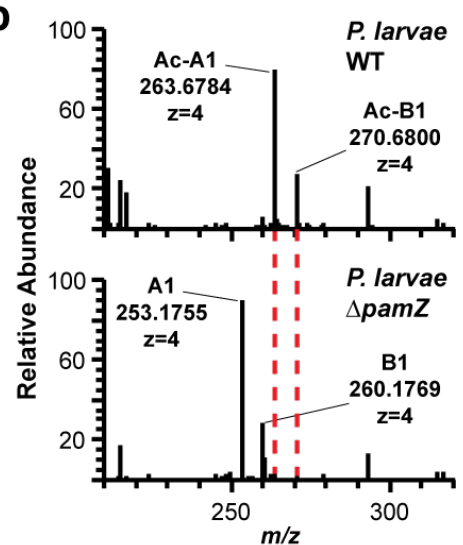

Figure 7. Self-resistance of $\boldsymbol{P}$. larvae against paenilamicin. a Deactivation of a paenilamicin mixture A1/B1 (left) was tested by an agar diffusion assay against $P$. larvae WT (top) and $P$. larvae $\Delta$ pamZ (bottom). The negative control (right) contained water only. b HPLC-ESI MS spectra of cell lysates of P. larvae WT (top) and P. larvae $\Delta$ pamZ (bottom) are depicted. Relevant peaks for paenilamicin (A1/B1) and $N$-acetylpaenilamicin (Ac-A1/Ac-B1) species are labeled with corresponding $m / z$ ratios $(z=4)$.

$\mathrm{N}$-acetylation functions as an efficient self-protection mechanism by scavenging paenilamicin that reenters the cells of $P$. larvae. However, this mechanism may not apply to intracellular paenilamicin after its release from the NRPS-PKS assembly line. Instead, it seems very likely that an inactive precursor, i.e. a prodrug, of paenilamicin is produced to mask the strong antibacterial activity before cellular export. Along these lines, the biosynthetic gene cluster of paenilamicin ${ }^{22}$ harbors the pamJ gene, which shows significant sequence similarity to a cyclic-peptide export $A B C$ transporter with $D$-asparagine-specific peptidase activity that has been reported to be involved in a prodrug resistance mechanism in nonribosomal peptide synthesis $^{39-42}$. The peptidase recognizes and cleaves an $\mathrm{N}$-acyl-D-asparagine unit of the prodrug. Accordingly, $P$. larvae must have developed a dual self-resistance mechanism against paenilamicin both potentially addressing the N-terminal GIm/Aga region, specifically the N-terminal amino group at Aga-6 position, as modification site. Not only P. larvae, but also other bacteria belonging to the Firmicutes refer to a dual self-resistance mechanism associated with NRPS-PKS-derived compounds like amicoumacin ${ }^{41,43}$, zwittermicin ${ }^{30}$ and edeine ${ }^{44}$ 
317 (Figure S29). In a very recent study, paenilamicin B2 showed an inhibitory effect $\left(\mathrm{IC}_{50}\right.$ of 318 approx. $0.3 \mu \mathrm{M}$ ) on the E. coli ribosome in vitro, whereas the diastereomer PamB2_2 was

319 approx. 10-fold and the $\mathrm{N}$-acetylpaenilamicin B2 approx. 100-fold less active ${ }^{28}$. The 320 modifications of the N-terminal amino group at Aga-6 thus point to the importance of the $\mathrm{N}$ 321 terminal GIm/Aga region as major pharmacophore mediating recognition at the molecular 322 target.

323 The insights into the pharmacophore region of paenilamicins and the structure of PamZ 324 including its substrate-binding pocket may lead to the development of inhibitors against the 325 self-resistance factor to weaken the bee larvae pathogen. In summary, these results expand 326 our knowledge of the molecular strategies exploited by $P$. larvae to survive in its ecological 327 niche - knowledge that is needed to combat this pathogen and secure health of bee colonies 328 worldwide. 


\section{Methods}

\section{Bacterial strains and culture conditions}

331 The field strain Paenibacillus larvae (P. larvae) 04-309 (DSM 25430) and the deletion mutant

332 04-309 $\triangle$ pamZ were cultivated as follows: bacteria were grown on Columbia sheep blood agar

333 (CSA, Thermo Fisher Scientific Oxoid, Schwerte, Germany) medium plates at $37^{\circ} \mathrm{C}$ for 2-

3343 days. A preculture of $2 \mathrm{~mL}$ Mueller-Hinton-yeast-phosphate-glucose-pyruvate (MYPGP) ${ }^{45}$

335 medium was inoculated with a single colony and grown overnight. A $50 \mathrm{~mL}$ culture of MYPGP

336 broth was inoculated with the preculture to reach an optical density measured at $600 \mathrm{~nm}$

$337\left(\mathrm{OD}_{600}\right)$ of 0.001 . This main culture was incubated at $30^{\circ} \mathrm{C}$ for $72 \mathrm{~h}$ with gentle shaking ( $\left.80 \mathrm{rpm}\right)$.

338 Cultures were centrifuged at $3200 \mathrm{~g}, 4^{\circ} \mathrm{C}$ for $30 \mathrm{~min}$ and supernatants were stored at $-20^{\circ} \mathrm{C}$

339 until further use. Escherichia coli (E. coli) BL21-Gold(DE3) cells were cultivated in Luria-Bertani

340 (LB) medium at $37^{\circ} \mathrm{C}$ and $180 \mathrm{rpm}$. The medium was supplemented with kanamycin $\left(50 \mu \mathrm{g} \mathrm{mL}^{-}\right.$

$341^{1}$ ) as antibiotic based on the selection marker of the plasmid after transformation. Indicator

342 strains like $B$. megaterium used for the agar diffusion assay were cultivated in LB medium at

$343 \quad 37^{\circ} \mathrm{C}$ and $180 \mathrm{rpm}$.

\section{Deletion mutant generation}

345 The generation of the pamZ deletion mutant was realized through a well-established protocol for $P$. larvae using the TargeTron Gene Knockout System (Sigma-Aldrich, Germany) based on group II intron insertion as previously described ${ }^{10,13,14,23,46}$. The pamZ gene of $P$. larvae DSM 25430 (GenBank: CP003355.1, range from 1729003 to 1729830) was disrupted via sitespecific insertion of a $900 \mathrm{bp}$-sized bacterial mobile group II intron LI.LtrB from Lactococcus lactis at position 118 from the start codon. The intron was previously modified to enable specific insertion at this site identified by a computer algorithm provided by the manufacturer (http://www.sigma-genosys.com/targetron) with primers also identified by the computer algorithm (Table S4). After successful cloning and transformation into P. larvae DSM 25430, screening for $P$. larvae DSM 25430 deletion mutants with the intron integrated in the pamZ gene was done via PCR with pamZ-specific primers (Table S4, Figure S30a). Growth of the pamZ deletion mutant in liquid MYPGP medium was not significantly altered in comparison to the wild type strain (Figure $\mathbf{S 3 0 b}$, two-way-ANOVA, $\mathrm{p}=0.6486$ ). In brief, growth curves were obtained as follows. $P$. larvae starting cultures had an optical density at $600 \mathrm{~nm}\left(\mathrm{OD}_{600}\right)$ of 0.001 and were covered with mineral oil for anaerobic conditions. Cultures were grown in a of the $\mathrm{OD}_{600}$ took place hourly for $48 \mathrm{~h}$. The experiment was repeated three times with three biological replicates with three technical replicates each. Representative results are shown. 
Cells of $P$. larvae were picked from CSA plates, resuspended in $50 \mu \mathrm{L}$ water and incubated at $95^{\circ} \mathrm{C}$ for $10 \mathrm{~min}$. They were centrifuged at $5000 \mathrm{~g}$ for $5 \mathrm{~min}$ and the supernatant containing the DNA was stored at $-20^{\circ} \mathrm{C}$ until further use. For gene amplification for cloning procedures, pure DNA was isolated by using the MasterPure ${ }^{\mathrm{TM}}$ Gram Positive DNA Purification Kit (Epicentre, Illumina, San Diego, CA, USA) following the manufacturer's instructions.

\section{Plasmid construction and transformation}

371 Primers were designed for the amplification of the pamZ gene from $P$. larvae DSM 25430 and purchased from Thermo Fisher Scientific (Table S5). The gene pamZ was cloned into vector $\mathrm{pET} 28 \mathrm{a}(+)$ introducing an N-terminal histidine-tag and a TEV site. Reactions were performed in the following conditions: initial denaturation at $95^{\circ} \mathrm{C}$ for $5 \mathrm{~min}$, followed by 30 cycles (105 s per cycle) at $98^{\circ} \mathrm{C}$ for $30 \mathrm{~s}$, at $61^{\circ} \mathrm{C}$ for $30 \mathrm{~s}$, and at $72^{\circ} \mathrm{C}$ for $45 \mathrm{~s}$, followed by a final extension step at $72^{\circ} \mathrm{C}$ for $10 \mathrm{~min}$. The amplicons were purified and digested with Nhel and Xhol, ligated with the digested pET28a(+) vector, and transformed into E. coli BL21-Gold(DE3).

\section{Heterologous expression and protein purification}

379 Terrific broth (TB) medium was inoculated with an overnight culture of pET28a_pamZ transformed in E. coli $\mathrm{BL21-Gold(DE3)}$ cells to reach an $\mathrm{OD}_{600}$ of 0.1 for the purification of PamZ. The culture was incubated at $37^{\circ} \mathrm{C}$ and $180 \mathrm{rpm}$ until $\mathrm{OD}_{600}$ of $0.8-1.0$. Expression was induced by addition of $0.2 \mathrm{mM}$ (f.c.) isopropyl $\beta$-D-1-thiogalactopyranoside (IPTG). Cells were further incubated at $160 \mathrm{rpm}, 18^{\circ} \mathrm{C}$ for $20 \mathrm{~h}$. Cells were harvested at $5000 \mathrm{~g}, 4^{\circ} \mathrm{C}$ for $30 \mathrm{~min}$ and the pellet was resuspended in lysis buffer $(500 \mathrm{mM}$ sodium chloride, $50 \mathrm{mM}$ TRIS/HCL $\mathrm{pH}$ 8.0, $20 \mathrm{mM}$ imidazole). Then, magnesium chloride, DNase, lysozyme and benzamidine were added into the solution. The cell disruption was performed by the cell homogenizer at 15000 psi (Constant Systems Ltd, United Kingdom). Cell lysate was centrifuged at $50000 \mathrm{~g}$, $4^{\circ} \mathrm{C}$ for 30 min (Beckman Coulter, Avanti J-26 XP). Supernatant was loaded onto a His-Trap column using an ÄKTA protein purification system (GE Healthcare Life Sciences). The chromatography was run with a two-step gradient started with $100 \%$ starting buffer $(500 \mathrm{mM}$ sodium chloride, $50 \mathrm{mM}$ TRIS/HCL pH 8.0, $20 \mathrm{mM}$ imidazole) and switched to $50 \%$ elution buffer (500 mM sodium chloride, $50 \mathrm{mM}$ TRIS/HCL pH 8.0, $250 \mathrm{mM}$ imidazole) within $10 \mathrm{CV}$ to elute the $\mathrm{His}_{6}$-tagged PamZ. A His-Trap crude FF column (GE Healthcare Life Sciences) was used for this purification. Fractions of interest were collected and combined to increase protein concentration. Subsequently, TEV protease (1 $\mathrm{mg}$ per $10 \mathrm{mg}$ of protein) was added into the concentrated protein solution and incubated at $4^{\circ} \mathrm{C}$ for $16 \mathrm{~h}$. The $\mathrm{N}$-terminal, TEVcleavable $\mathrm{His}_{6}$-tag was separated from the untagged PamZ by a second nickel affinity chromatography. A size exclusion chromatography was performed with a HiLoad 16/600 
401 flow rate was set to $1 \mathrm{~mL} \mathrm{~min}^{-1}$. Fractions of interest were collected again, verified by SDS-

402 PAGE and Coomassie staining, and then concentrated. Protein samples were flash-frozen in

403 liquid nitrogen and stored at $-80^{\circ} \mathrm{C}$ for further applications.

\section{Analytical size exclusion chromatography}

405 Mixture $A$ and $B$ were used as standards. Mixture A contained aprotinin ( $\left.3 \mathrm{mg} \mathrm{mL}^{-1}\right)$, carbonic 406 anhydrase $\left(3 \mathrm{mg} \mathrm{mL}^{-1}\right)$, conalbumin $\left(3 \mathrm{mg} \mathrm{mL}^{-1}\right)$ and mixture $B$ ribonuclease $\left(3 \mathrm{mg} \mathrm{mL}^{-1}\right)$, 407 ovalbumin $\left(4 \mathrm{mg} \mathrm{mL}^{-1}\right)$. The chromatograms of mixture $A$ and $B$ were acquired as references 408 to determine the oligomeric state of PamZ. Untagged PamZ (1.25 mg mL $\left.{ }^{-1}\right)$ was prepared to 409 obtain the best fitted chromatogram. The size exclusion chromatography was run with the 410 ÄKTA protein purification system (GE Healthcare Life Sciences), equipped with Superdex 75 411 10/300 GL and run with buffer solution (150 mM sodium chloride, $20 \mathrm{mM}$ TRIS/HCL pH 8.0).

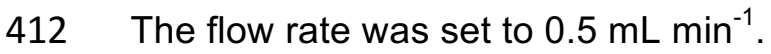

\section{Protein crystallization, structure determination and refinement}

414 For crystallization experiments, PamZ was concentrated to $71 \mathrm{mg} \mathrm{mL}^{-1}$. Crystallization was performed in a sitting drop vapor diffusion setup at $293 \mathrm{~K}$. The reservoir solution was composed of $40 \%$ (w/v) PEG $3350,50 \mathrm{mM}$ ammonium sulfate and $100 \mathrm{mM}$ sodium acetate at $\mathrm{pH}$ 4.6.

417 Prior to flash cooling, the crystals were cryo-protected in a reservoir solution supplemented with $20 \%(\mathrm{v} / \mathrm{v})$ glycerol. Diffraction data were collected at beamline 14.2 at BESSY. Diffraction data were processed with XDS (Table S3) ${ }^{47}$. The structure was solved by molecular replacement with PHASER ${ }^{48}$ using the N-terminal domain of the PDB-ID 3G3S. Since the C-

421 terminal domain could not be readily placed the model was completed by Arp/wArp ${ }^{49}$. The 422 structure was refined by maximum-likelihood restrained refinement in PHENIX ${ }^{50,51}$. Model 423 building and water picking was performed with $\mathrm{COOT}^{52}$. Hydrogen atoms for protein residues 424 and ligands were generated with PHENIX.REDUCE ${ }^{53}$. Model quality was evaluated with 425 MolProbity and the JCSG validation server (JCSG Quality Control Check v3.1) ${ }^{54}$. Figures were 426 prepared using PyMOL (Schroedinger Inc.). Electrostatic potentials were calculated with 427 APBS $^{55}$. Structural alignments have been performed using SSM $^{32}$. Structural homologues 428 were identified with the DALI server ${ }^{56}$. Structural interfaces were analyzed with the PISA 429 server ${ }^{57,58}$.

\section{Compound isolation (supernatant)}

$4311 \mathrm{~L}$ of frozen supernatants of $P$. larvae ATCC 9545 or DSM 25430 cultures were thawed and 432 then incubated with Amberlite XAD16 adsorption beads $(1 \mathrm{~g}$ of beads per $10 \mathrm{~mL}$ culture filtrate, 433 Sigma, St. Louis, MO, USA) and stirred for $16 \mathrm{~h}$ at room temperature. Then, the flow through 434 was separated from the beads and a three-step gradient elution applied using $1 \mathrm{~L}$ of $10 \%(\mathrm{v} / \mathrm{v})$ methanol followed by $1 \mathrm{~L}$ each of $90 \%(\mathrm{v} / \mathrm{v})$ methanol and $90 \%(\mathrm{v} / \mathrm{v})$ methanol plus $0.1 \%$ formic 

acetyl)paenilamicin-containing fractions were concentrated and purified subsequently by using a Grace HPLC column (GROM-Sil 120 ODS-5-ST, $10 \mu \mathrm{m}, 250 \times 20 \mathrm{~mm}$ ) coupled to an Agilent 1100 HPLC system (Agilent Technologies, Waldbronn, Germany) with a MWD UV detector. formic acid as solvent $A$ and acetonitrile plus $0.1 \%(\mathrm{v} / \mathrm{v})$ formic acid as solvent $\mathrm{B}$. The gradient started from $3 \%(\mathrm{v} / \mathrm{v})$ to $15 \%(\mathrm{v} / \mathrm{v})$ solvent $B$ for $8 \mathrm{~min}$, followed by $100 \%(\mathrm{v} / \mathrm{v})$ solvent $\mathrm{B}$ for $7 \mathrm{~min}$, and finished with an isocratic gradient of $100 \%(\mathrm{v} / \mathrm{v})$ solvent $\mathrm{B}$ for $3 \mathrm{~min}$. The flow rate was set to $20 \mathrm{~mL} \mathrm{~min}^{-1}$. In the next step, paenilamicin-containing fractions were concentrated, adjusted with trifluoroacetic acid to approximately $\mathrm{pH} 2.0$ to increase separation and purified by an Agilent HPLC column (PLRP-S, $100 \AA$, $10 \mu \mathrm{m}, 150 \times 25 \mathrm{~mm}$ ) coupled to an Agilent 1100 HPLC system with a MWD UV detector for the separation of the native ( $N$-acetyl)paenilamicin variants. ( $N$-acetyl)paenilamicin was purified by using an isocratic gradient elution using water plus $0.1 \%(\mathrm{v} / \mathrm{v})$ trifluoroacetic acid as solvent $A$ and acetonitrile plus $0.1 \%(\mathrm{v} / \mathrm{v})$ trifluoroacetic acid as solvent $B$. The isocratic gradient was started with $1 \%(\mathrm{v} / \mathrm{v})$ solvent $B$ for $8 \mathrm{~min}$, followed by a linear gradient from $1 \%(\mathrm{v} / \mathrm{v})$ to $95 \%(\mathrm{v} / \mathrm{v})$ solvent $\mathrm{B}$ for $7 \mathrm{~min}$, and finished with an isocratic gradient of $95 \%(\mathrm{v} / \mathrm{v})$ solvent $\mathrm{B}$ for $5 \mathrm{~min}$. The flow rate was set to $20 \mathrm{~mL} \mathrm{~min}^{-1}$. $(\mathrm{N}-$ acetyl)paenilamicin-containing fractions were dried in vacuo, lyophilized to obtain pure compound and verified by HPLC-ESI-MS and ${ }^{1} \mathrm{H}-\mathrm{NMR}$ spectroscopy.

\section{Compound extraction (cell pellet)}

456 After cultivation of $P$. larvae DSM 25430 and its deletion mutant $\Delta p a m Z$, the cells were harvested and the cell pellets resuspended in $50 \%$ methanol $(1 \mathrm{~g}$ per $2 \mathrm{~mL}$ solvent). The cells were disrupted by sonication (Branson Sonifier 250) for five cycles (15 s each cycle). In between of each cycle, the cell lysate was incubated on ice for $60 \mathrm{~s}$. The lysate was centrifuged at $5000 \mathrm{~g}, 15^{\circ} \mathrm{C}$ for $30 \mathrm{~min}$. The supernatant was analyzed for $\mathrm{N}$-acetylpaenilamicin and paenilamicin by HPLC-ESI MS.

\section{In vitro activation assay}

463 A reaction mixture consisted of $0.5 \mathrm{mM}$ paenilamicin, $7.5 \mu \mathrm{M}$ PamZ, $1 \mathrm{mM}$ acetyl-CoA, $1.5 \mathrm{mM}$ sodium phosphate buffer ( $\mathrm{pH}$ 7.8). Also, samples were prepared each without enzyme and cosubstrate as negative controls. The reaction mixture was incubated at $30^{\circ} \mathrm{C}$ for $8 \mathrm{~h}$. PamZ was removed by Amicon centrifugal filters (Merck KGaA, Germany) using a 10 kDa molecular weight cut-off filter. Deactivation of paenilamicin was tested against $B$. megaterium as indicator strain by agar diffusion assay and analyzed with HPLC-ESI MS and NMR.

For the NMR experiment, excessive acetyl-CoA from the in vitro activation assay was removed by using an HPLC column (Phenomenex, Luna C18[2], $100 \AA, 5 \mu \mathrm{m}, 100 \times 4.6 \mathrm{~mm}$ ) 
472 MWD UV detector. The separation was accomplished by a linear gradient elution using water 473 plus $0.1 \%(\mathrm{v} / \mathrm{v})$ formic acid as solvent $A$ and acetonitrile plus $0.1 \%(\mathrm{v} / \mathrm{v})$ formic acid as 474 solvent $B$. The gradient started from $3 \%(\mathrm{v} / \mathrm{v})$ to $15 \%(\mathrm{v} / \mathrm{v})$ solvent $\mathrm{B}$ for $8 \mathrm{~min}$, followed by $475100 \%(\mathrm{v} / \mathrm{v})$ solvent $\mathrm{B}$ for $2 \mathrm{~min}$, and finished with an isocratic gradient of $100 \%(\mathrm{v} / \mathrm{v})$ solvent $\mathrm{B}$ 476 for $2 \mathrm{~min}$. The flow rate was set to $0.6 \mathrm{~mL} \mathrm{~min}^{-1}$.

477 For the determination of substrate specificity and stereoselectivity of PamZ including 478 synthetic diastereomers, a reaction mixture consisted of $0.5 \mathrm{mM}$ paenilamicin B2 (also for diastereomers), $7.5 \mu \mathrm{M}$ PamZ, $1 \mathrm{mM}$ acetyl-CoA, $1.5 \mathrm{mM}$ sodium phosphate buffer ( $\mathrm{pH} 7.8$ ).

480 Also, samples were prepared each without enzyme and co-substrate as negative controls. The 481 reaction mixture was incubated at $30^{\circ} \mathrm{C}$ for $2 \mathrm{~h}$. PamZ was removed by Amicon centrifugal 482 filters (Merck KGaA, Germany) using a $10 \mathrm{kDa}$ molecular weight cut-off filter. After removal of 483 the protein, the reaction mixture was tested against $B$. megaterium as indicator strain by agar 484 diffusion assay and analyzed with HPLC-ESI MS.

\section{Agar diffusion assay}

$48620 \mathrm{~mL}$ of LB medium including $0.75 \%$ (w/v) agar was inoculated with bacterial suspension of 487 B. megaterium with a final $\mathrm{OD}_{600}$ of 0.05 . After solidification of the agar plate, holes were punched into the agar for activity testing. $10 \mu \mathrm{L}$ of each sample was pipetted into the holes after removal of PamZ and the plate incubated at $37^{\circ} \mathrm{C}$ overnight.

\section{In vivo activation assay}

491 The growth of wild type $P$. larvae DSM 25430 was compared to the growth of $P$. larvae 492 DSM $25430 \Delta$ pamZ in the presence of purified paenilamicin A1/B1 from bacteria supernatants 493 in an agar diffusion assay. In brief, pre-cultures with $5 \mathrm{~mL}$ volume were grown in MYPGP broth 494 at $37^{\circ} \mathrm{C}$ while gently shaking overnight. Liquid lukewarm MYPGP agar was inoculated with $495 P$. larvae pre-cultures to result in a final optical density $\mathrm{OD}_{600}$ of 0.05 . Agar plates were poured and let harden. Meanwhile, $20 \mu \mathrm{L}$ of paenilamicin A1/B1 dissolved in MilliQ (in total $160 \mu \mathrm{g}$ per disk) were dispensed on filter disks and dried at room temperature. The dry filter disks were placed on the agar. The agar plates were incubated at $37^{\circ} \mathrm{C}$ overnight. Clear zones of inhibition around the filter disks were indicative of a loss of paenilamicin resistance.

\section{Mass spectrometry analysis}

A 6530 Accurate-Mass Quadrupole Time-of-Flight (Q-TOF) LC/MS (Agilent Technologies, Waldbronn, Germany) was used to verify ( $N$-acetyl)paenilamicin-containg fractions during the isolation and purification of paenilamicin, The Q-TOF was attached to an Agilent 1260 Infinity HPLC system and equipped with a HPLC column (Poroshell 120, EC-C8, $2.7 \mu \mathrm{m}, 2.1$ x $50 \mathrm{~mm}$, 
and acetonitrile plus $0.1 \%(\mathrm{v} / \mathrm{v})$ formic acid as solvent $\mathrm{B}$, followed by an isocratic gradient of $100 \%(\mathrm{v} / \mathrm{v})$ for $1 \mathrm{~min}$. The column was equilibrated with $5 \%(\mathrm{v} / \mathrm{v})$ solvent $\mathrm{B}$ for $3 \mathrm{~min}$. The flow

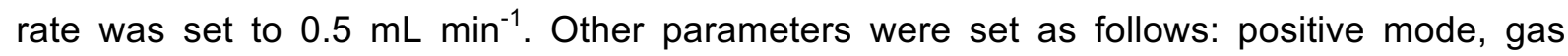
temperature to $300^{\circ} \mathrm{C}$, drying gas to $8 \mathrm{~L} \mathrm{~min}^{-1}$, nebulizer to $35 \mathrm{psi}$, sheath gas temperature to $350^{\circ} \mathrm{C}$, sheath gas flow to $11 \mathrm{~L} \mathrm{~min}^{-1}$, capillary voltage to $3500 \mathrm{~V}$, fragmentor to $330 \mathrm{~V}$, skimmer to $65 \mathrm{~V}$, acquired rate to $1 \mathrm{spec} \mathrm{s}^{-1}$.

A LTQ-Orbitrap XL hybrid ion trap-orbitrap (Thermo Fisher Scientific $\mathrm{GmbH}$, Bremen, Germany) was used to verify the in vitro activation assays and to generate tandem mass spectra of paenilamicin and $\mathrm{N}$-acetylpaenilamicin in data-dependent acquisition (DDA) mode. The LTQ-Orbitrap XL was attached to an analytical HPLC 1200 Infinity system (Agilent Technologies, Waldbronn, Germany) and equipped with a HPLC column (Poroshell 120, ECC18, $2.7 \mu \mathrm{m}, 2.1 \times 50 \mathrm{~mm}$, Agilent Technologies, Waldbronn, Germany). HPLC was run with a linear gradient using water plus $0.1 \%(\mathrm{v} / \mathrm{v})$ formic acid as solvent $A$ and acetonitrile plus $0.1 \%$ $(\mathrm{v} / \mathrm{v})$ formic acid as solvent B from $5 \%(\mathrm{v} / \mathrm{v})$ to $100 \%(\mathrm{v} / \mathrm{v})$ solvent $B$ for $6 \mathrm{~min}$, followed by an isocratic gradient of $100 \%(\mathrm{v} / \mathrm{v})$ solvent $B$ for $2 \mathrm{~min}$. The column was equilibrated with $5 \%(\mathrm{v} / \mathrm{v})$ solvent $B$ for $2 \mathrm{~min}$. The flow rate was set to $0.5 \mathrm{~mL} \mathrm{~min}^{-1}$. The ESI source parameters were set as follows: product ion spectra were recorded in data-dependent acquisition (DDA) mode with a mass range from $\mathrm{m} / \mathrm{z} 180$ to $\mathrm{m} / \mathrm{z} 2000$ (MS1: FTMS, normal, 60000, full, positive. MS2: FTMS, normal, 30000). The parameter for the DDA mode was set as follows: dynamic exclusion (repeat count: 3 , repeat duration: $30 \mathrm{~s}$, exclusion size list: 50 , exclusion duration: $180 \mathrm{~s}$ ), current scan event (minimum signal threshold: 10000), activation (type: CID, default charge state: 2 , isolation width: $m / z$ 2.0, normalized collision energy: 35 , activation Q: 0.25 , activation time: $30 \mathrm{~ms}$ ).

\section{Nuclear magnetic resonance spectroscopy}

NMR experiments were performed on a Bruker Avance III $700 \mathrm{MHz}$ spectrometer equipped with a room-temperature TXI probe (Bruker, Karlsruhe, Germany). TopSpin 3.5 (Bruker, Karlsruhe, Germany) was used for data acquisition and processing. Spectra analysis was performed using NMRFAM-SPARKY ${ }^{59-61}$. ${ }^{1} \mathrm{H}$ and ${ }^{1} \mathrm{H}-{ }^{13} \mathrm{C}$ HSQC spectra of paenilamicin and $\mathrm{N}$-acetylpaenilamicin were recorded using samples in $\mathrm{D}_{2} \mathrm{O}$ with $0.1 \%$ acetic acid-d4 at $298 \mathrm{~K}$. ${ }^{1} \mathrm{H}-{ }^{13} \mathrm{C} \mathrm{HSQC}$ spectra were recorded with acquisition times of $120 \mathrm{~ms}$ and $9 \mathrm{~ms}$ in the direct ${ }^{1} \mathrm{H}$ and indirect ${ }^{13} \mathrm{C}$ dimension, respectively. A delay $\Delta / 2$ of $1.72 \mathrm{~ms}$ was used for INEPT transfers corresponding to ${ }^{1} J_{\mathrm{HC}}$ of $145 \mathrm{~Hz}$. Apodization of time domain data was performed using a squared sine-bell function shifted by $90^{\circ}$. The 2D data was processed by applying linear forward prediction in the indirect ${ }^{13} \mathrm{C}$ dimension and zero filling prior to Fourier transformation. ${ }^{1} \mathrm{H}$ chemical shifts were referenced externally using a sample of trimethylsilylpropanoic acid (TMSP- $d_{4}$, Deutero $\mathrm{GmbH}$, Kastellaun, Germany) in $\mathrm{D}_{2} \mathrm{O}$ with $0.1 \%$ 
544 correction factor of $f_{13 \mathrm{C} / 1 \mathrm{H}}=0.251449530^{62,63}$. Chemical shift perturbations (CSPs) were

545 calculated using the following equation ${ }^{64}$ :

$$
C S P=\sqrt{\left(f \times \Delta \delta_{13 \mathrm{C}}\right)^{2}+\left(\Delta \delta_{1 \mathrm{H}}\right)^{2}}
$$

547 where $\Delta \delta_{13 \mathrm{C}}$ and $\Delta \delta_{1 \mathrm{H}}$ correspond to the ${ }^{13} \mathrm{C}$ and ${ }^{1} \mathrm{H}$ chemical shift differences between

548 paenilamicin $\mathrm{B} 2$ and $\mathrm{N}$-acetylpaenilamicin $\mathrm{B} 2$ for each carbon-proton pair. We used a

549 weighting factor $f$ of 0.06 to account for the much larger chemical shift dispersion in the ${ }^{13} \mathrm{C}$

550 dimension (ca. $60 \mathrm{ppm}$ ) compared to that in the ${ }^{1} \mathrm{H}$ dimension (ca. $3.5 \mathrm{ppm}$ ).

\section{Data Availability}

552 The coordinates and structure factors have been deposited in the Protein Data Bank under

553 accession code 7B3A. Diffraction images have been deposited at www.proteindiffraction.org.

\section{References}

555 1. Klein, A. M. et al. Importance of pollinators in changing landscapes for world crops. Proc. Biol. Sci. 274, 303-313 (2007).

2. Cornman, R. S. et al. Pathogen webs in collapsing honey bee colonies. PLoS One 7, e43562 (2012).

3. Genersch, E. et al. Reclassification of Paenibacillus larvae subsp. pulvifaciens and Paenibacillus larvae subsp. larvae as Paenibacillus larvae without subspecies differentiation. Int. J. Syst. Evol. Microbiol. 56, 501-511 (2006).

4. Lindström, A., Korpela, S. \& Fries, I. Horizontal transmission of Paenibacillus larvae spores between honey bee (Apis mellifera) colonies through robbing. Apidologie 39, 515-522 (2008).

5. Genersch, E., Ashiralieva, A. \& Fries, I. Strain- and genotype-specific differences in virulence of Paenibacillus larvae subsp. larvae, a bacterial pathogen causing American foulbrood disease in honeybees. Appl. Environ. Microbiol. 71, 7551-7555 (2005).

6. Rauch, S., Ashiralieva, A., Hedtke, K. \& Genersch, E. Negative correlation between individual-insect-level virulence and colony-level virulence of Paenibacillus larvae, the etiological agent of american foulbrood of honeybees. Appl. Environ. Microbiol. 75,

573 7. Djukic, M. et al. How to kill the honey bee larva: Genomic potential and virulence mechanisms of Paenibacillus larvae. PLoS One 9, e90914 (2014).

8. Beims, H. et al. Discovery of Paenibacillus larvae ERIC V: Phenotypic and genomic comparison to genotypes ERIC I-IV reveal different inventories of virulence factors which correlate with epidemiological prevalences of American Foulbrood. Int. J. Med. 
Microbiol. 310, 151394 (2020).

9. Morrissey, B. J. et al. Biogeography of Paenibacillus larvae, the causative agent of American foulbrood, using a new multilocus sequence typing scheme. Environ. Microbiol. 17, 1414-1424 (2015).

582

10. Fünfhaus, A., Poppinga, L. \& Genersch, E. Identification and characterization of two novel toxins expressed by the lethal honey bee pathogen Paenibacillus larvae, the causative agent of American foulbrood. Environ. Microbiol. 15, 2951-2965 (2013).

585

11. Ebeling, J. et al. Characterization of the toxin PIx2A, a RhoA-targeting ADPribosyltransferase produced by the honey bee pathogen Paenibacillus larvae. Environ. Microbiol. 19, 5100-5116 (2017).

12. Garcia-Gonzalez, E. \& Genersch, E. Honey bee larval peritrophic matrix degradation during infection with Paenibacillus larvae, the aetiological agent of American foulbrood of honey bees, is a key step in pathogenesis. Environ. Microbiol. 15, 2894-2901 (2013).

592

13. Garcia-Gonzalez, E. et al. Paenibacillus larvae Chitin-Degrading Protein PICBP49 Is a Key Virulence Factor in American Foulbrood of Honey Bees. PLoS Pathog. 10, e1004284 (2014).

14. Poppinga, L. et al. Identification and functional analysis of the S-layer protein SpIA of Paenibacillus larvae, the causative agent of American Foulbrood of honey bees. PLoS Pathog. 8, e1002716 (2012).

15. Fünfhaus, A. \& Genersch, E. Proteome analysis of Paenibacillus larvae reveals the existence of a putative S-layer protein. Environ. Microbiol. Rep. 4, 194-202 (2012).

16. Müller, S., Garcia-Gonzalez, E., Genersch, E. \& Süssmuth, R. D. Involvement of secondary metabolites in the pathogenesis of the American foulbrood of honey bees caused by Paenibacillus larvae. Nat. Prod. Rep. 32, 765-778 (2015).

17. Dang, T. \& Süssmuth, R. D. Bioactive Peptide Natural Products as Lead Structures for Medicinal Use. Acc. Chem. Res. 50, 1566-1576 (2017).

606

18. Hutchings, M., Truman, A. \& Wilkinson, B. Antibiotics: past, present and future. Curr. Opin. Microbiol. 51, 72-80 (2019).

608

19. Beceiro, A., Tomás, M. \& Bou, G. Antimicrobial resistance and virulence: A successful 609 or deleterious association in the bacterial world? Clin. Microbiol. Rev. 26, 185-230 (2013).

610

20. Wyatt, M. A. et al. Staphylococcus aureus nonribosomal peptide secondary metabolites regulate virulence. Science 329, 294-296 (2010).

612 21. Süssmuth, R. D. \& Mainz, A. Nonribosomal Peptide Synthesis-Principles and Prospects. Angew. Chem. Int. Ed. 56, 3770-3821 (2017). 
peptide/polyketide antibiotic from the bee pathogen Paenibacillus larvae. Angew. Chem. Int. Ed. 53, 10821-10825 (2014).

23. Garcia-Gonzalez, E. et al. Biological effects of paenilamicin, a secondary metabolite antibiotic produced by the honey bee pathogenic bacterium Paenibacillus larvae. MicrobiologyOpen 3, 642-656 (2014).

24. Holst, E. C. An antibiotic from a bee pathogen. Science 102, 593-594 (1945).

25. Neuwald, A. F. \& Landsman, D. GCN5-related histone $N$-acetyltransferases belong to a diverse superfamily that includes the yeast SPT10 protein. Trends Biochem. Sci. 22, 154-155 (1997).

26. Dyda, F., Klein, D. C. \& Hickman, A. B. GCN5-related N-acetyltransferases: A structural overview. Annu. Rev. Biophys. Biomol. Struct. 29, 81-103 (2000).

27. Magnet, S. \& Blanchard, J. S. Molecular insights into aminoglycoside action and resistance. Chem. Rev. 105, 477-498 (2005).

28. Bulatov, T. et al. Total synthesis and biological evaluation of paenilamicins from the honey bee pathogen Paenibacillus larvae. Submitted (2021).

29. Altschul, S. F., Gish, W., Miller, W., Myers, E. W. \& Lipman, D. J. Basic local alignment search tool. J. Mol. Biol. 215, 403-410 (1990).

30. Stohl, E. A., Brady, S. F., Clardy, J. \& Handelsman, J. ZmaR, a novel and widespread antibiotic resistance determinant that acetylates zwittermicin A. J. Bacteriol. 181, 5455-5460 (1999).

31. Vetting, M. W. et al. Structure and functions of the GNAT superfamily of acetyltransferases. Arch. Biochem. Biophys. 433, 212-226 (2005).

32. Krissinel, E. \& Henrick, K. Secondary-structure matching (SSM), a new tool for fast protein structure alignment in three dimensions. Acta Crystallogr. D Biol. Crystallogr. 60, 2256-2268 (2004).

33. Wolf, E. et al. Crystal Structure of a GCN5-Related N-acetyltransferase: Serratia marcescens Aminoglycoside 3-N-acetyltransferase. Cell 94, 439-449 (1998).

34. Favrot, L., Blanchard, J. S. \& Vergnolle, O. Bacterial GCN5-Related NAcetyltransferases: From Resistance to Regulation. Biochemistry 55, 989-1002 (2016).

35. Vetting, M. W., Magnet, S., Nieves, E., Roderick, S. L. \& Blanchard, J. S. A Bacterial Acetyltransferase Capable of Regioselective N-Acetylation of Antibiotics and Histones. Chem. Biol. 11, 565-573 (2004).

36. Vetting, M. W., Hegde, S. S., Javid-Majd, F., Blanchard, J. S. \& Roderick, S. L. Aminoglycoside 2'-N-acetyltransferase from Mycobacterium tuberculosis in complex with coenzyme A and aminoglycoside substrates. Nat. Struct. Biol. 9, 653-658 (2002).

37. Vetting, M. W., Roderick, S. L., Yu, M. \& Blanchard, J. S. Crystal structure of mycothiol 
synthase (Rv0819) from Mycobacterium tuberculosis shows structural homology to the GNAT family of N-acetyltransferases. Protein Sci. 12, 1954-1959 (2003).

38. Bhatnagar, R. S. et al. Structure of $N$-myristoyltransferase with bound myristoylCoA and peptide substrate analogs. Nat. Struct. Biol. 5, 1091-1097 (1998).

39. Reimer, D., Pos, K. M., Thines, M., Grün, P. \& Bode, H. B. A natural prodrug activation mechanism in nonribosomal peptide synthesis. Nat. Chem. Biol. 7, 888-890 (2011).

40. Brotherton, C. A. \& Balskus, E. P. A prodrug resistance mechanism is involved in colibactin biosynthesis and cytotoxicity. J. Am. Chem. Soc. 135, 3359-3362 (2013).

41. Li, Y. et al. Directed natural product biosynthesis gene cluster capture and expression in the model bacterium Bacillus subtilis. Sci. Rep. 5, (2015).

42. Li, Y.-X., Zhong, Z., Hou, P., Zhang, W.-P. \& Qian, P.-Y. Resistance to nonribosomal peptide antibiotics mediated by D-stereospecific peptidases. Nat. Chem. Biol. 14, 381387 (2018).

43. Park, H. B., Perez, C. E., Perry, E. K. \& Crawford, J. M. Activating and attenuating the amicoumacin antibiotics. Molecules 21, 824 (2016).

44. Westman, E. L., Yan, M., Waglechner, N., Koteva, K. \& Wright, G. D. Self resistance to the atypical cationic antimicrobial peptide edeine of Brevibacillus brevis Vm4 by the $N$-acetyltransferase EdeQ. Chem. Biol. 20, 983-990 (2013).

45. Dingman, D. W. \& Stahly, D. P. Medium promoting sporulation of Bacillus larvae and metabolism of medium components. Appl. Environ. Microbiol. 46, 860-869 (1983).

46. Zarschler, K., Janesch, B., Zayni, S., Schaffer, C. \& Messner, P. Construction of a gene knockout system for application in Paenibacillus alvei CCM 2051T, exemplified by the S-layer glycan biosynthesis initiation enzyme WsfP. Appl. Environ. Microbiol. 75, 3077-3085 (2009).

47. Kabsch, W. XDS. Acta Crystallogr. D Biol. Crystallogr. 66, 125-132 (2010).

48. McCoy, A. J. et al. Phaser crystallographic software. J. Appl. Crystallogr. 40, 658-674 (2007).

49. Langer, G., Cohen, S. X., Lamzin, V. S. \& Perrakis, A. Automated macromolecular model building for X-ray crystallography using ARP/wARP version 7. Nat. Protoc. 3, 1171-1179 (2008).

50. Adams, P. D. et al. PHENIX: A comprehensive Python-based system for macromolecular structure solution. Acta Crystallogr. D Biol. Crystallogr. 66, 213-221 (2010).

51. Afonine, P. V. et al. Towards automated crystallographic structure refinement with phenix.refine. Acta Crystallogr. D Biol. Crystallogr. 68, 352-367 (2012).

52. Emsley, P., Lohkamp, B., Scott, W. G. \& Cowtan, K. Features and development of Coot. Acta Crystallogr. D Biol. Crystallogr. 66, 486-501 (2010). 
689

690

691

692

693

694

695

696

697

698

699

700

701

702

703

704

705

706

707

708

709

710

711

712

713

714

715

716

717

718

719

720

721

722

723

724

725

53. Word, J. M., Lovell, S. C., Richardson, J. S. \& Richardson, D. C. Asparagine and glutamine: Using hydrogen atom contacts in the choice of side-chain amide orientation. J. Mol. Biol. 285, 1735-1747 (1999).

54. Chen, V. B. et al. MolProbity: All-atom structure validation for macromolecular crystallography. Acta Crystallogr. D Biol. Crystallogr. 66, 12-21 (2010).

55. Baker, N. A., Sept, D., Joseph, S., Holst, M. J. \& McCammon, J. A. Electrostatics of nanosystems: Application to microtubules and the ribosome. Proc. Natl. Acad. Sci. U. S. A. 98, 10037-10041 (2001).

56. Holm, L. \& Rosenström, P. Dali server: Conservation mapping in 3D. Nucleic Acids Res. 38, W545-549 (2010).

57. PDBePISA (Proteins, Interfaces, Structures and Assemblies). Available at: https://www.ebi.ac.uk/pdbe/prot_int/pistart.html.

58. Krissinel, E. \& Henrick, K. Inference of Macromolecular Assemblies from Crystalline State. J. Mol. Biol. 372, 774-797 (2007).

59. Goddard, T. D. \& Kneller, D. G. Sparky 3. (2008).

60. Lee, W., Tonelli, M. \& Markley, J. L. NMRFAM-SPARKY: Enhanced software for biomolecular NMR spectroscopy. Bioinformatics 31, 1325-1327 (2015).

61. Lee, W. et al. Integrative NMR for biomolecular research. J. Biomol. NMR 64, 307-332 (2016).

62. Wishart, D. S. et al. $1 \mathrm{H}, 13 \mathrm{C}$ and $15 \mathrm{~N}$ chemical shift referencing in biomolecular NMR. J. Biomol. NMR 6, 135-140 (1995).

63. Markley, J. L. et al. Recommendations for the presentation of NMR structures of proteins and nucleic acids: IUPAC-IUBMB-IUPAB Inter-Union Task Group on the Standardization of Data Bases of Protein and Nucleic Acid Structures Determined by NMR Spectroscopy. J. Biomol. NMR 12, 1-23 (1998).

64. Williamson, M. P. Using chemical shift perturbation to characterise ligand binding. Prog. Nucl. Magn. Reson. Spectrosc. 73, 1-16 (2013).

\section{Acknowledgements}

We thank the Deutsche Forschungsgemeinschaft (DFG, German Research Foundation) with SU 239/21-1 (project no. 279410221) and with RTG 2473 "Bioactive Peptides" (project no. 392923329) for funding the project. This research was also funded by the Ministries responsible for Agriculture of the German Federal States of Brandenburg, Sachsen-Anhalt, Thüringen, Sachsen and the Senate of Berlin, Germany, as well as by the DFG, grant numbers GE1365/1-1, GE1365/1-2, and GE1365/2-1 to E.G. We are grateful to Claudia Alings, Freie Universität Berlin, for help with crystallization. We acknowledge access to beamlines of the BESSY II storage ring (Berlin, Germany) via the Joint Berlin MX-Laboratory sponsored by Helmholtz-Zentrum Berlin für Materialien und Energie, Freie Universität Berlin, Humboldt- 
726 Universität zu Berlin, Max-Delbrück-Centrum, Leibniz-Institut für Molekulare Pharmakologie

727 and Charité-Universitätsmedizin Berlin.

\section{Author information}

729 Affiliations

730 Institut für Chemie, Technische Universität Berlin, Berlin, Germany

731 Tam Dang, Sebastian Müller, Ranko Skobalj, Timur Bulatov, Sebastian Gensel, Andi Mainz,

732 Roderich D. Süssmuth

733 Institut für Chemie und Biochemie, Strukturbiochemie, Freie Universität Berlin, Berlin,

734 Germany

735 Bernhard Loll, Markus C. Wahl

736

Macromolecular Crystallography, Helmholtz Zentrum Berlin für Materialien und Energie, Berlin, Germany

738

Markus C. Wahl

Institute for Bee Research, Department of Molecular Microbiology and Bee Diseases,

741 Julia Ebeling, Josefine Göbel, Elke Genersch

742 Institut für Mikrobiologie und Tierseuchen, Fachbereich Veterinärmedizin, Freie

743 Universität Berlin, Berlin, Germany

744 Elke Genersch

\section{Contributions}

746 T.D., S.M., R.S., A.M. and R.D.S. designed the experiments. T.D., S.M. and R.S. purified 747 paenilamicins and PamZ and also conducted the in vitro activation assays. T.D. set up the 748 tandem-MS experiments and analyzed related data. B.L. performed the crystallization and 749 elucidated the protein structure of PamZ. J.E. generated the deletion mutant $P$. larvae $\Delta$ pamZ 750 and performed the in vivo activation assay of paenilamicin against wild type and deletion 751 mutant. T.B. and S.G. synthesized paenilamicin B2 and the two diastereomers. J.G. cultivated $752 \quad P$. larvae wild type and deletion mutant $\triangle$ pamZ and prepared the corresponding supernatants.

753 A.M. performed the NMR experiments, acquired and analyzed the related data. T.D., M.C.W., 754 E.G., A.M. and R.D.S. wrote the manuscript.

\section{Ethics declarations}

\section{Competing interests}

757 The authors declare no competing interests. 
bioRxiv preprint doi: https://doi org/10.1101/2021 11 23,$469742 ;$ this version posted November $23,2021$. The copyright holder for this preprint (which was not certified by peer review) is the author/funder, who has granted bioRxiv a license to display the preprint in perpetuity. It is made available under aCC-BY-NC-ND 4.0 International license.

\section{Supplementary Information}

759 Supplementary Figures and Tables. 